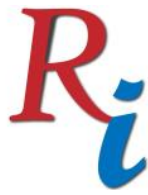

Asia Proceedings of Social Sciences

(APSS)

www.readersinsight.net/APSS

\title{
HYBRID OF CHEMISTRY LEARNING ACTIVITIES IN SECONDARY SCHOOL THROUGH DEVELOPMENT OF THE FLIPPED \\ ClASSROOM MODEL
}

\section{Maria Paristiowati*}

Department of Chemistry Education

Universitas Negeri Jakarta

Indonesia

\section{Ucu Cahyana}

Department of Chemistry Education Universitas Negeri Jakarta

Indonesia

\section{Ella Fitriani}

Department of Chemistry Education

Universitas Negeri Jakarta

Indonesia

*Corrosponding author's Email: maria.paristiowati@gmail.com

Peer-review under responsibility of $3^{\text {rd }}$ Asia International Multidisciplanry Conference 2019 editorial board

(http://www.utm.my/asia/our-team/)

(c) 2019 Published by Readers Insight Publisher,

lat 306 Savoy Residencia, Block 3 F11/1,44000 Islamabad. Pakistan,

info@ readersinsight.net

This is an open access article under the CC BY-NC-ND license (http://creativecommons.org/licenses/by-nc-nd/4.0/). 


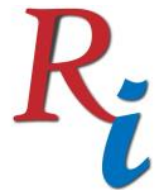

\section{Asia Proceedings of Social Sciences \\ (APSS) \\ www.readersinsight.net/APSS}

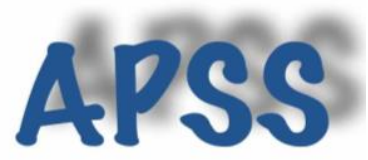

Rese a r ch H igh I ight s

In this study hybridization of chemistry learning activities in secondary school was carried out through the development of flipped classroom models. Activity hybridization is the composition of learning inside and outside the classroom with appropriate supporting modules and learning videos. Variations in the composition of learning activities inside and outside the classroom are done through a flipped classroom model that is integrated with the ProblemBased Learning (PBL) and Inquiry models. The research was conducted by the development research method from Richey and Klein, with the implementation stage using experimental strategies, $2 \times 2$ treatment by level design and nonequivalent control group design. The results of the implementation show that on the topic of the Reaction Rate, the hybridization composition of activities inside and outside the classroom with flipped classroom-PBL models can improve scientific literacy and flipped classroom models-inquiry can improve student learning outcomes in secondary school.

\section{Research Objectives}

The purpose of the study is to get the composition of appropriate learning activities inside and outside the classroom through an inverted class model that is integrated with problem-based learning models and inquiry on the topic of reaction rates.

\section{Methodology}

This research is a category of product design and development research (Richey and Klein, 2007) which was tested through a pilot study using quantitative strategies (experiments).

In this study, the product is a flipped classroom learning design with a variety of activities inside and outside the classroom. The stages in Richey and Klein's design and development research are as follows:

1. Identifying design and development research problem

2. Design and development research methodology

3. Selecting participants and settings

4. Collecting design and development research data

5. Interpreting design and development findings

Stage 1 and 2 are stages of designing flipped classroom learning. Stage 3, 4 and 5 are the implementation stages of the design of classroom flipped learning. The implementation phase is carried out through a pilot study on reaction rate topic in two schools. Flipped classroom learning is integrated with inquiry and problem based learning (PBL) models. The implementation of the flipped classroom inquiry uses nonequivalent control group design. Flipped classroom-PBL implementation uses $2 \times 2$ treatment by level design.

\section{Results}

The results showed that students' scientific literacy on the topic of the reaction rate given by the problem-based learning-flipped classroom model was higher than the Problem-Based Learning-Traditional Classroom model. This is due, in the problem-based learning-flipped classroom model, learning in the classroom becomes more effective, because the subject matter has been given by the teacher outside the classroom through learning videos (Eichler \& Peeples, 2016; Olakanmi, 2017). Students can prepare themselves for classroom learning by watching videos at home so they can construct their initial knowledge before classroom learning activities (Hwang, Lai, and Wang, 2015). The time needed by the teacher to explain 


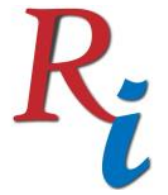

\section{Asia Proceedings of Social Sciences \\ (APSS) \\ www.readersinsight.net/APSS}

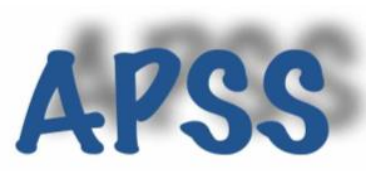

the subject matter can be reduced and can be filled more with active and in-depth learning activities, such as discussion and problem solving, especially problems in the environment related to science and technology. Thus, through this way students can have a deeper understanding of science and technology so that it also has an impact on the increase in scientific literacy of these students.

The results also show that inquiry learning with flipped classroom models provides a different learning experience for students (Paristiowati, Fitriani, \& Aldi, 2017). The teacher gives direction to students to carry out distance learning activities independently by learning through learning videos that have been designed and limited only to knowledge and understanding of the concepts and facts in each sub chapter of the material before coming to class. Then during class activities, the teacher provides inquiry learning, which facilitates students to be more active in exploring questions, conducts discussion activities related to problem solving in small groups, presentations, and practices in the laboratory.

\section{Findings}

The classroom flipped model can be combined with a problem-based learning model (PBL) and inquiry, with a composition of learning activities inside and outside the different classes, namely $50 \%$ and $67.7 \%$.

\section{Acknowledgement}

This work is supported by Universitas Negeri Jakarta and Ministry of Research, Technology and Higher Education of the Republic of Indonesia through research fund 2017-2018.

\section{References}

Eichler, J. F., \& Peeples, J. (2016). Flipped classroom modules for large enrollment general chemistry courses: A low barrier approach to increase active learning and improve student grades. Chemistry Education Research and Practice, 17(1), 197-208. https://doi.org/10.1039/c5rp00159e.

Hwang, G.-J., Lai, C.-L., \& Wang, S.-Y. (2015). Seamless flipped learning: a mobile technologyenhanced flipped classroom with effective learning strategies. Journal of Computers in Education, 2(4), 449-473. https://doi.org/10.1007/s40692-015-0043-0

Olakanmi, E. E. (2017). The Effects of a Flipped Classroom Model of Instruction on Students' Performance and Attitudes Towards Chemistry. Journal of Science Education and Technology, 26(1), 127-137. https://doi.org/10.1007/s10956-016-9657-x

Paristiowati, M., Fitriani, E., \& Aldi, N. H. (2017). The effect of inquiry-flipped classroom model toward students' achievement on chemical reaction rate. AIP Conference Proceedings, 1868(August). https://doi.org/10.1063/1.4995105

Richey, Rita C. and James D. Klein. (2007). Design and Development Research, Methods Strategies and Issues, New Jersey: Lawrence Erlbaum Associates. 